DE DE GRUYTER OPEN

\title{
MOLECULAR CHARACTERIZATION OF ESBL GENE IN CITROBACTER SPP AND ANTIBACTERIAL ACTIVITY OF OMEGA-3 AGAINST RESISTANT ISOLATES
}

\author{
Mayyada Farhan Darwees \\ Department of Biology, Faculty of Science, Kufa University, Najaf, Iraq, \\ e-mail: mayadaalsaqeeri@uokufa.edu.iq
}

\begin{abstract}
This study aimed to investigated the prevalence and resistance pattern of different Citrobacter species phenotypically and genotypically to $\beta$-lactam and some most common antibiotics then evaluate the antibacterial activity of omega-3 extracted from flaxseed against isolates that harboring resistance genes. 19 Citrobacter isolates were isolated from 100 stool and urine samples taken from patients attended to AL-Sadar Hospital during June-December 2016. Clinical samples were cultured on specific media, thereafter isolates were identified depending on morphological, biochemical characteristics and VITK-2. The results showed that the Citrobacter comprise $24 \%$ of isolated bacteria which divided into 11 (14.1\%) were C. freundii, 5 (6.41\%) C. kosaeri and C. farmeri were $3(3.8 \%)$. The antagonistic activity was evaluated by observing a clear zone of inhibition growth, the results showed that all Citrobacter (100\%) isolates were resistant to Ampicillin, cefoxitin and sensitive to Imipinim, also the isolates showed different degrees of resistant to $\beta$-lactam antibiotics initially. By confirmatory test the results observed 17/19 (89.4\%) isolated were ESBL producers finally using PCR technique to detect blagenes (blaCTX-M, OXA, SHV and Z). The results revealed that 14/17 (82.3) of potential ESBL producing Citrobacter were harbor one or more of ESBL genes they included 10 of $C$. freundii and 4 of $C$. koseri. The extraction of essential fatty acid semicarbazide (omega-3) from Linum usitatissium (Flax seed) were tested to evaluate their activity against resistant isolates, results explained broad spectrum antibacterial property of EFASC compounds against resistant bacteria. In conclusion, this study found increase prevalence of MDR Citrobacter spp as causative agents in clinical cases. Considering antibacterial activity of EFASC, it was observed highly activity against resistant pathogens deservedly, therefore attention must be paid to development their used as alternative antibiotics.
\end{abstract}

Key words: Citrobacter infection, ESBL-genes, omega-3 antibacterial activity

Recommended form of citation: Darwees, M. F., 2016. Molecular characterization of ESBL gene in Citrobacter spp and antibacterial activity of omega-3 against resistant isolates. Acta Environ. Univ. Comenianae (Bratislava). 24(2): 5-13. DOI: 10.1515/aeuc-2016-0007

\section{INTRODUCTION}

Citrobacter is a gram negative rods motile bacteria, one members of Enterobacteriaceae. It name derived from its ability to use citrate as a sole carbon source (JANDA et al. 1994). Infections with 
Citrobacter spp. have been increasing importancy as a cause of serious nosocomial outbreaks and difficult to treated by most common antibiotic (NADA et al. 2004; SHIH et al. 1996). Locally, several studies referred to the prevalence levels of Citrobacter infections (AL-HASNAWI 2014; AL-HISSNAWY et al. 2012; TUWAIJ 2016). Extended spectrum B-lactam (ESBL) a members of $\beta$-lactamases enzymes hydrolyzes the $\beta$-lactams ring lead to loss of bactericidal activity of wide variety of antibiotics including third generation cephalosporins, penicillins and monobactam (HARVEY \& CHAMPE 2012). The increase prevalence of ESBL producing gram negative bacteria is a significant problem in treating bacterial infection, in addition to different side effects like allergy to some antibiotic, nephrotoxicity, ototoxicity, and alteration of normal gut flora. For this reason seeking to a new alternative medicine to control pathogens with reduced side effects has become a crucial part of drug development research. On the other hand, green medicine has been used for the medication of different bacterial disease (FUAD et al. 2012).

Linum usitatissimum L. (Flaxseed) the annual plant. Its' seeds containing about 36 to $40 \%$ of oil is a rich source of the following unsaturated essential fatty acids: Omega 3 (linolenic acid), Omega 6 (linoleic acid) and oleic acid content (WANG et al. 2017). Linolenic acid and other compound of (EFAs) used as possible new agents to treat skin infections caused by P. acnes and S. aureus (DESBOIS \& LAWLOR 2013). Several study confirmed the successful treatment of USFA against $S$. aureus, $P$. aerogenosa, L. monocytogenes (SHIN et al. 2007) semicarbazides are the raw material of semicarbazones that possess a wide spectrum of antibacterial activities (SINGHAL \& PAUL 2011).

\section{METHODOLOGICALLY BACTERIAL CHARACTERIZATION}

A total of 100 clinical specimens from Stool and Urine were collected under aseptic condition. These specimens were collected from patients attending to Al-Sadar Medical City in AL-Najaf province inoculated on MacConkey agar and XLD agar (Oxoid Cambridge, UK) and incubated at $37{ }^{\circ} \mathrm{C}$ for 24 h. The morphological characteristics of the colonies including size, shape, color, were recorded, the suspected Citrobacter were relevant by biochemical test (MACFADDIN 2000), then finally confirmed by using Vitek-2 Compact (Bio Mérieux, France).

Antibiogram test: Antibiotics susceptibility was carried out on all isolate using Kirby Bauer disc diffusion method. Results were inter operated by measuring the zone of inhibition in $\mathrm{mm}$. Then using results of cefotaxime, ceftazidime, ceftriaxone, and aztreonam (30 $\mu \mathrm{g}$ of each one) as initially screened to detect $\beta$-lactam resistant isolates (ESBL Production) according to (CLSI 2014). Then confirmed by the disk approximation test according to (BATCHOUN et al. 2009). Any augmentation (increase in diameter of inhibition zone) between the central Amoxiclav disk and any of the cefotaxime, ceftazidime, ceftriaxone, and aztreonam (surrounded the plate around the Amoxiclav). Disks that showing resistance or intermediate susceptibility was recorded.

Genomic DNA extraction: The cell pellets from all resistant isolates were used to extract genomic DNA by Genomic DNA Mini extraction kit (Geneaid, USA) following the manufacturer's instructions. Extracted DNA was kept in sterile eppendorf tubes and stored at $-20{ }^{\circ} \mathrm{C}$ prior to $\mathrm{PCR}$.

Detection of resistance genes: PCR amplification for detection the four bla genes, bla-CTX-M, bla-TEM, bla-SHV and bla-OXA were carried out according to information of Bioneer corporation, Korea) as shown in Table 1 . PCR mixtures $(25 \mu \mathrm{L})$ contained $5 \mu \mathrm{L}$ of DNA template, $12.5 \mu \mathrm{L}$ master mix (Promega, USA) and $1.25 \mu \mathrm{L}$ of each primer and $5 \mu \mathrm{L}$ of sterilized distilled water was used. PCR amplifications were performed in Agilent, USA Thermo Cycler according to condition (HASSAN et al. 2013; COLOM et al. 2003; SVÄRD 2007). PCR products were electrophoresized on 1.5\% agarose gels, stained with ethidium bromide (Biobasic, Canada) and visualized by UV illumination and were photographed by a Cleaver gel documentation system (Biometer/Germany). 
Tab. 1: The sequnces of synthesized oligonucleatoide

\begin{tabular}{|c|c|c|c|c|}
\hline Primer name & & - ) & Molecular weight of mplicon (bp) & Ref. \\
\hline$C T X-M$ & $\begin{array}{l}\mathbf{F} \\
\mathbf{R}\end{array}$ & $\begin{array}{l}\text { CGCTGTTGTTAGGAAGTGTG } \\
\text { GGCTGGGTGAAGTAAGTGAC }\end{array}$ & 754 & 16 \\
\hline SHV & $\begin{array}{l}\mathbf{F} \\
\mathbf{R} \\
\end{array}$ & $\begin{array}{c}\text { AGGATTGACTGCCTTTTTG } \\
\text { ATTTGCTGATTTCGCTCG } \\
\end{array}$ & 392 & 17 \\
\hline$O X A$ & $\begin{array}{l}\mathbf{F} \\
\mathbf{R}\end{array}$ & $\begin{array}{c}\text { ATATCTCTACTGTTGCATCTCC } \\
\text { AAACCCTTCAAACCATCC }\end{array}$ & 619 & 18 \\
\hline TEM & $\begin{array}{l}\mathbf{C} \\
\mathbf{H} \\
\end{array}$ & $\begin{array}{l}\text { ATCAGCAATAAACCAGC } \\
\text { CCCCGAAGAACGTTTTC }\end{array}$ & 516 & 18 \\
\hline
\end{tabular}

Plant collection: Flaxseed were obtained from seller of herbal and medicinal plants in Al-Najaf City. The plants were washed with distilled water, then air dried, powdered, and stored in refrigerator at $4{ }^{\circ} \mathrm{C}$ for further processes (AHMAD et al. 2017).

Preparation of oil: The oil of Flaxseed were extracted with hexan solvent (1:4 w:v) by continous extraction in a soxhlet apparatus (Preciso, England) for 12 hours. Then isolation of EFA from oil using cleavenger (Shepreth, England) according to (AHMAD et al. 2017). Purity and Identification of EFAomega3 compounds by TLC was carried out according to (HARBORNE 1984).

Preparation of EFA - Semicarbazide (EFASC): One gram of EFA (omega-3) were dissolved in $4 \mathrm{ml}$ of methanol and 1:1 $\mathrm{H} 2 \mathrm{SO} 4$, then $4 \mathrm{gm}$ of thiosemicarbazide in methanol were added to this solution with constant stirring at room temperature for $4 \mathrm{hr}$ and then added $\mathrm{NH} 4 \mathrm{OH}$ till alkaline stir for about $15 \mathrm{~min}$ and kept it overnight. Crystals was filtered, dried and recrystallized (BORHADE 2014). Determination of antibacterial activity Agar well diffusion method was used to determine the antibacterial activity of EFASC of Flaxseed compounds according to (EGHAREVBA et al. 2010).

Statistical analysis: Analysis of data was performed by using Statistical Package for Social Science (SPSS) system/ version 17 and Microsoft Office Excel 2007. Results expressed as mean \pm S.D. $\mathrm{P}$-value was considered significant when it is less than 0.05 . The analysis of variance (ANOVA) were used.

\section{RESULTS}

\section{Identification of Citrobacter}

Nineteen of bacterial isolated were identified as Citrobacter spp from 78 positive bacterial growth on MacConkey agar recovered from the 100 clinical specimens collected with a frequency (24.3\%). The isolates were represented by $11(14.1 \%)$ isolates of $C$. freuendii, $5(6.41 \%)$ C. kosori and 3 isolates (3.8\%) were identify as C. farmeri (Fig. 1), while 59 isolates $(75.65 \%)$ showed growth of other gram negative bacteria which included Klebsiella species, E. coli, Pseudomonase and Proteus species.

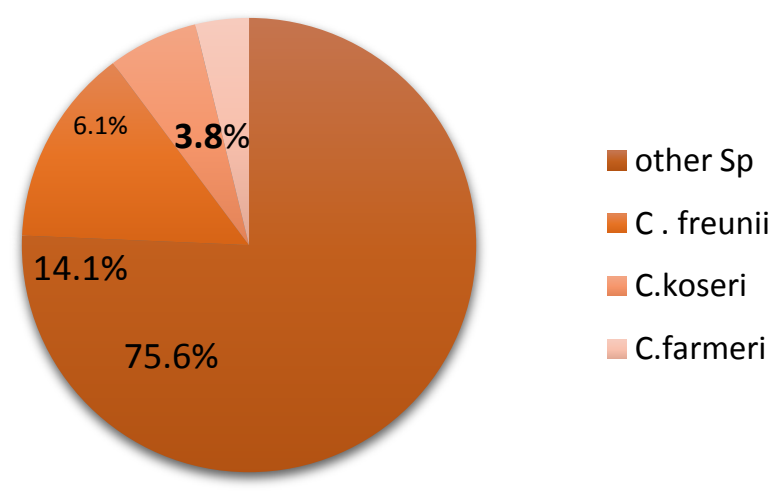

Fig. 1: Pie chart showing the distribution of Citrobacter spp. 


\section{Antibiogram test}

The results of antibiogram tests for all Citrobacter species to 11 antibiotics were summarized in Figure 2. The results revealed that all isolates were multidrug resistant and all of them were $100 \%$ resistance to Ampicillin and Cefoxitin, while 100\% sensitive to Imipenem antibiotic. Among the thirdgeneration cephalosporins tested, $C$. freundii appear highly resistance against amox-clave and cefotaxime in $90.1 \%$ of isolates, while resistance to ceftazidime and cefriaxon was recorded in $81.8 \%$ of isolates, and various levels of resistance was observed towards oxacillin $72.7 \%$, Ciprofloxacin $54.5 \%$ and Gentamycin $63.6 \%$. The resistance pattern of C. koseri and C. farmeri were shown in Figure 2.

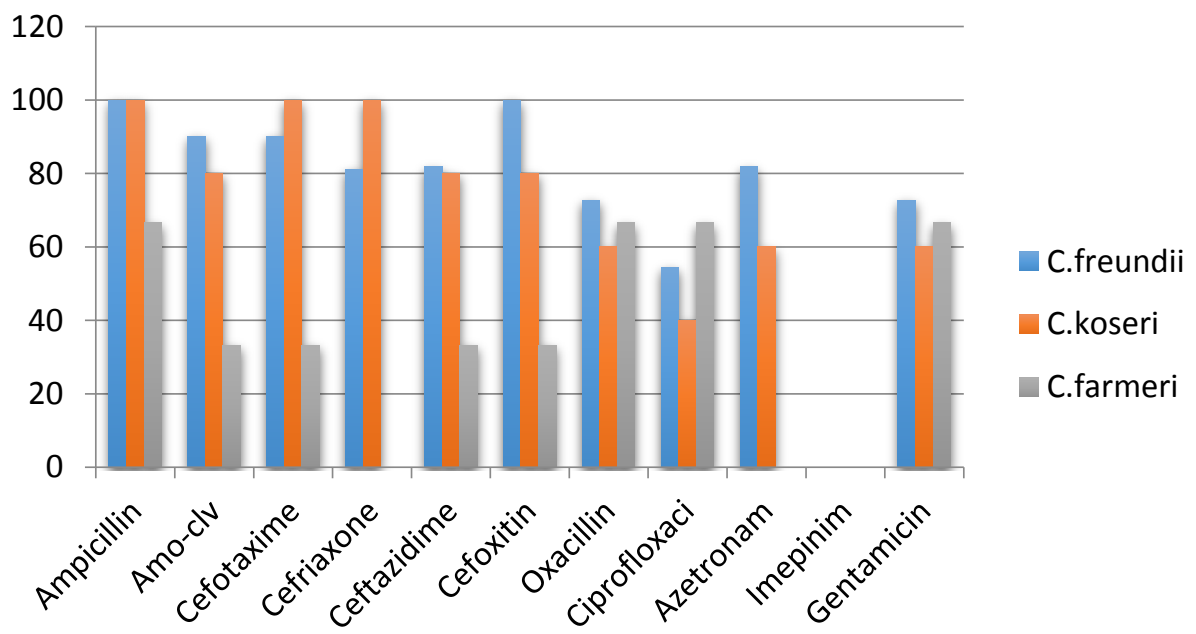

Fig. 2: Antibiotic resistance pattern of Citrobacter spp.

\section{Initially, Confirmatory and Detection of resistance genes}

As shown in Table 2 the results of initially and confirmatory test revealed that all Citrobacter isolates were gave a potential ESBL-producers initially, while the confirmed results showed that only $17 / 19$ (89.4\%) of the isolates were ESBL producers. The results for detection bla - genes (blaCTX-M , bla-TEM, bla-SHV and bla-OXA) by PCR revealed that 14/17 of potential ESBL producing Citrobacter were carried at least one of ESBL genes they included 10 of $C$. freundii and 4 of C. koseri. The results illustrated that 12 isolates were contained only one type of ESBL-genes as following 5 blaCTX-M, 3 bla-TEM, 2 bla-SHV and 2 bla-OXA genes. While, 2 isolates of $C$. freundii had the combination of two genes: one blaSHV genes combination with bla-CTX-M genes and one bla-TEM genes combination with blaCTX-M genes Table 2 and Figure 3.

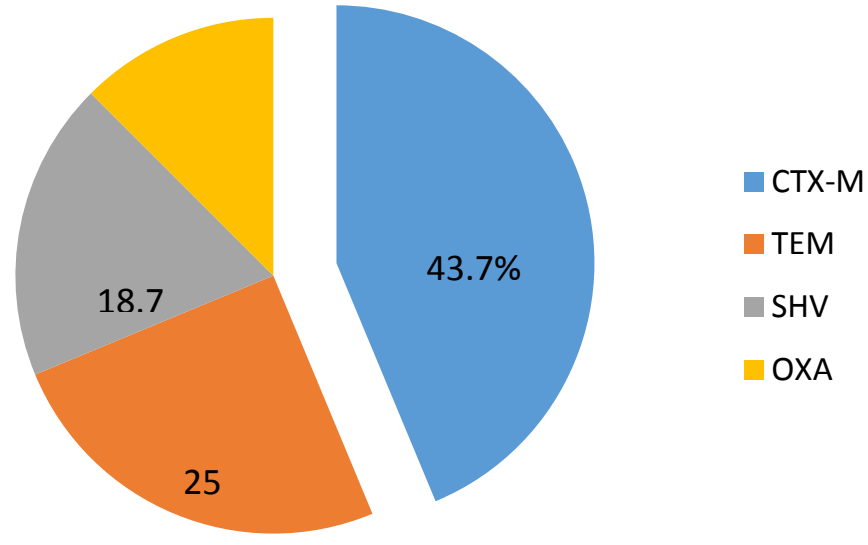

Fig. 3: ESBL-gene distribution in Citrobacter spp 
Tab. 2: The frequency of phenotypic, genotypic to antibiotic resistance in Citrobacter spp.

\begin{tabular}{|c|c|c|c|c|c|c|}
\hline \multirow[t]{2}{*}{ Name \& No. of isolate } & \multicolumn{2}{|c|}{ Phenotypic } & \multicolumn{4}{|c|}{ Genotypic } \\
\hline & Initial & Confirmatory & CTX-M & TEM & SHV & OXA \\
\hline C. f. 1 & & & - & & - & - \\
\hline C. f. 2 & & & - & & - & - \\
\hline C. f. 3 & & & & - & & - \\
\hline C. f. 4 & & & & & - & - \\
\hline C. f. 5 & & & & - & - & - \\
\hline C. f. 6 & & & - & - & - & \\
\hline C. f. 7 & & & - & - & - & \\
\hline C. f. 8 & & & - & - & & - \\
\hline C. f. 9 & & & & - & - & - \\
\hline C. f. 10 & & & & - & - & - \\
\hline C.f. 11 & & & - & - & - & - \\
\hline C. k. 1 & & & - & - & & - \\
\hline C. k. 2 & & & - & & - & - \\
\hline C. k. 3 & & & & - & - & - \\
\hline C. k. 4 & & & & - & - & - \\
\hline C. k. 5 & & & - & - & - & - \\
\hline C. far. 1 & & & - & - & - & - \\
\hline C. far. 2 & & - & - & - & - & - \\
\hline C. far. 3 & & - & - & - & - & - \\
\hline Total & 19 & 17 & 7 & 4 & 3 & 2 \\
\hline
\end{tabular}

\section{Frequency of ESBL-genes in Citrobacter spp}

The results of detection ESBL-gene distribution revealed that CTX-M $\beta$-lactamase was the most prevalent $(43.75 \%)$ among the ESBL producing isolates; followed by TEM - $\beta$-lactamase $(25 \%)$ and SHV $\beta$-lactamases were (18.75\%) while, OXA $\beta$-lactamase gave (12.5\%) Figure (3, 4 A, B, C, D).
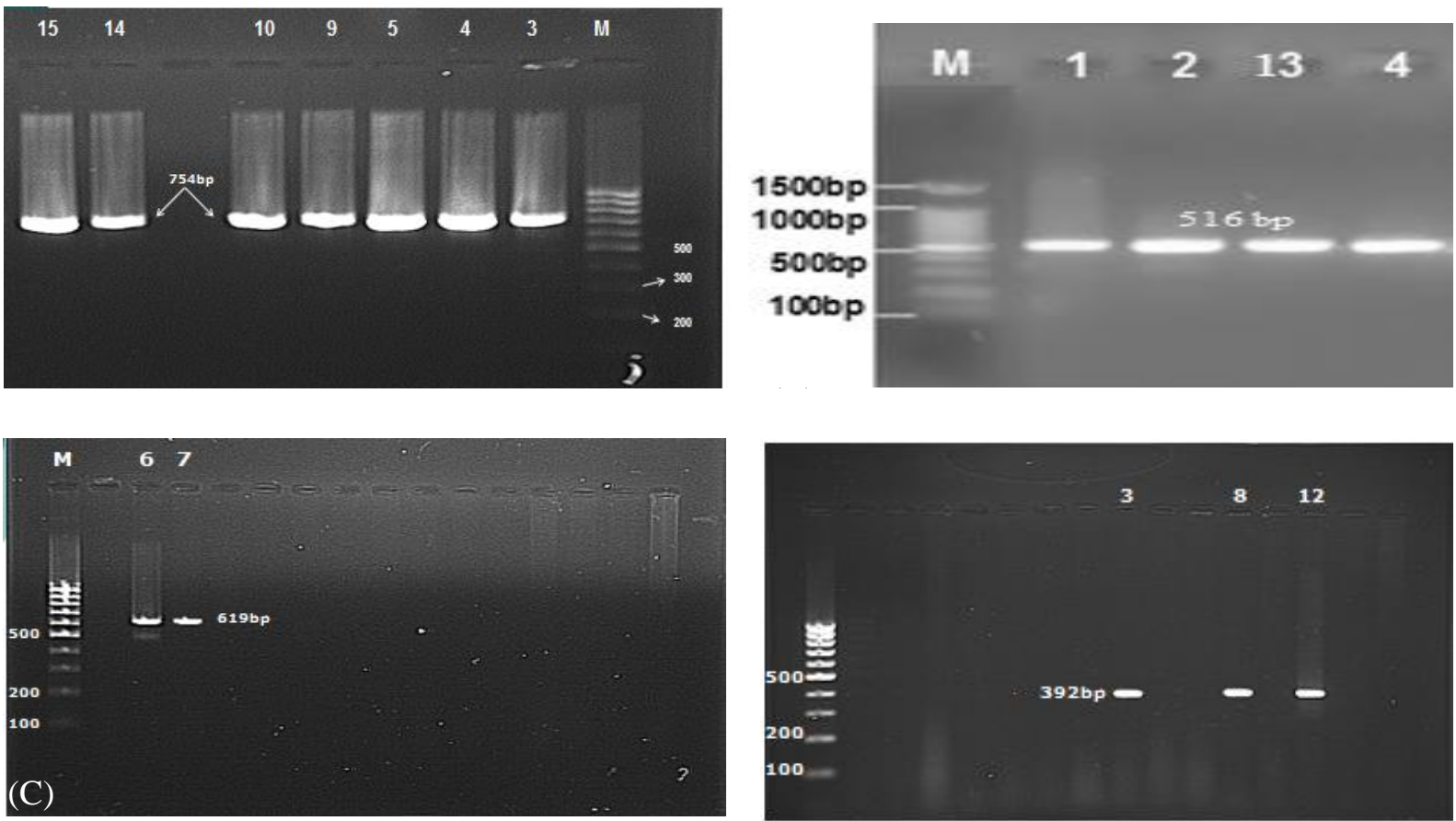

Fig. 4: Ethidium bromide stained agarose gel (1.5\% agrose gel, $75 \mathrm{~V}, 1.25$ hours) showing PCR amplification products with (A) CTX-M gene. Lane L: Ladder (100-1517 bp). Lane (3, 4, 5, 9, 10) C.f. No. 3, 4, 5, 9, 10 respectively. Lane $(14,15)$ C. koseri No. 3, 4. (B) TEM gene. Lane $(1,2,4)$ C. f. No. 1, 2, 4. Lane (13) C. koseri No. 2. (C) OXA gene. Lane (6, 7) C. f. No. 6, 7 (D) SHV gene. Lane (3, 8) C. f. No 3, 8, respectively. Lane (12) C. koseri No. 1 


\section{Thin Layer Chromatography}

The analysis of TLC chromatography of EFASC -omega3 as show in Table 3 revealed the presence of light brown spot on day light and light green by using UV light deeper after spraying with iodine spray, has $\mathrm{R} f$ equal to 0.37 that similar to the stander (EFASC-Omega3) which has $\mathrm{R} f$ value 0.37 appear as dark brown at day light and dark green under UV-light.

Tab. 3: Thin Layer Chromatography Essential Fatty Acid Semicarbazide of flaxseed (oil) compounds

\begin{tabular}{ccc}
\hline Properties & EFA (Omega 3) & EFASC \\
\hline $\mathrm{Rf}$ & 0.37 & 0.37 \\
Color by day-light & Dark Brown & Light Brown \\
Color under UV-Light & Dark Green & Light Green \\
\hline
\end{tabular}

\section{Evaluation the antibacterial activity of EFASC against resistant isolates}

The result of antibacterial activity illustrated that highest inhibition zone of extracts in $500 \mathrm{mg} / \mathrm{ml}$ concentration was demonstrated on the growth of $C$. koseri $31 \pm 0.93$ and $C$. freundii $29 \pm 0.93$. The results revealed highly effect with significant different in concentrations $(62.5,125,250$ and 500 $\mathrm{mg} / \mathrm{ml}$ ) of EFASC against isolates as explain in Table 4.

Tab. 4: Antibacterial activity of EFA SC against Citrobacter spp isolates

\begin{tabular}{ccc}
\hline Conc. of EFASC & C. freundii & C. koseri \\
\hline $500 \mathrm{mg} / \mathrm{ml}$ & $29 \pm 0.93$ & $31 \pm 0.93$ \\
$250 \mathrm{mg} / \mathrm{ml}$ & $27 \pm 1.20$ & $28 \pm 1.20$ \\
$125 \mathrm{mg} / \mathrm{ml}$ & $22 \pm 0.79$ & $24 \pm 0.99$ \\
$62.5 \mathrm{mg} / \mathrm{ml}$ & $20 \pm 0.75$ & $22 \pm 0.75$ \\
Cefreaxone & $19 \pm 0.5$ & $18 \pm 0.48$ \\
\hline
\end{tabular}

\section{DISCUSSION}

Citrobacter spp was gram negative colonies appear pink small convex on MacConkey agar and yellow, smooth, flat and round on XLD agar. Regarding to biochemical tests, all the 19 isolates of Citrobacter spp were lactose fermenting, motile and given positive test for catalase, methyl-red, citrate, and negative results for Indole (except $C$. koseri), oxidase, Voges-Proskuaer, also have ability to ferment glucose on kliglerś iron agar gave (A/A). The results demonstrate with ID message confidence level excellent by VITEK-2 compact system.

This study revealed that $C$. freundii was the most infectional agents recovered from different clinical specimens. In the same line, (AL-MuSLEMAWI TH. A. 2007) founded that $C$. freundii is the most common pathogen in frequency $6.6 \%$ of diarreatic patients, $2 \%$ of UTI patient , and $2 \%$ from wound followed by $C$. farmeri. This result online with study done by (SALIH et al.2016) state that Citrobacter spp isolated from UTI with $6 \%$ percent. According to (STEWART et al. 2017) they recognized that $C$. koseri were causative agents of UTI while (WARREN et al. 2000) isolated $C$. farmeri from UTI and wound infection.

Antimicrobial resistance is a major clinical problem on treating bacterial infection worldwide. However, Most of these isolates are considered multidrug resistant this results agree with study done locally by (TUWAIJ 2016) who found $C$. freundii isolates were $100 \%$ resistance to cefoxitin and revealed varying degree of resistance to ceftazidime, aztreonam, ciprofloxacin and gentamicin. The results were not different widely from the results of (HASSAN et al. 2014) they isolate $C$. freundii from UTI and founded that all Citrobacter isolates were resistance to cefotaxime and ceftriaxone and considered as MDR-bacteria. AL-MUSLEMAWI (2007) who observed that C. freundii were $100 \%$ 
resistance to $\beta$-lactam antibiotics while (METRI et al. 2013) They founded that C. koseri were predominant urine pathogen and recorded high rate of resistant to Cefexime, Amox-cla and Cephaloxin. Some Citrobacter isolate contain chromosomally mediated $\beta$-lactamases like Cephalosporinase and Penicillinase that lead to emergence of drug resistance and treatment failure despite initial susceptibility (SAMI et al. 2017). The resistance to Cephalosporins may be due to the phenomena minimizing membrane permeability based on membrane proteins purine (Porin-mediated permeability) this processes have a great impact of resistance to Cephalosporins (DANCER 2001).

In this study only $17(89.4 \%)$ of the isolates were ESBL producers (Table 2). The rates of resistance to Cephalosporins and monobactam might be as markers for the production of ESBL by these isolates which may be by producing the common group of class A $\beta$-lactamases, consisting of TEM, SHV and CTX-M $\beta$-lactamases that has extended hydrolytic spectrum activity on Cephalosporins (BUSH et al. 1995).

Ten of $C$. freundii and 4 of $C$. koseri were carried at least one of ESBL genes they included 12 isolates were contained only one type of ESBL-genes. While, 2 isolates had the combination of two genes. This finding in accordance with 27 they reported that $C$. freundii were ESBL-producers and they founded that isolates possess CTX_M 1 and 2 genes. Also, AL-HASNAWI (2014) who revealed that $C$. freundii were ESBL-producers and possess $100 \%$ CTX-M gene. The prevalence of bacteria which produced more than one type of ESBL enzymes is considered more dangerous for human hygiene (ERLANDSSON 2007).

This study show CTX-M $\beta$-lactamase was the most prevalent $(43.75 \%)$ among the ESBL producing isolates Figure 3. Several studies improved this results such as (AL-MUHANNAK 2010) in Najaf, who found that CTX-M $\beta$-lactamase was the most prevalent $(38.7 \%)$ among the ESBL producing G-ve isolates; followed by SHV (33.9\%); while, TEM and OXA $\beta$-lactamases were the less (27.4\% for each). Also, SHAHID (2010) who noticed in all the Citrobacter spp harboring bla genes and the prevalence of these genes as the following blaCTX-M, blaTEM, blaSHV, and bla ampC, respectively. Finally, PERILLI et al. (2005) revealed that C.koseri isolated from UTI patients were multidrug resistance and harporing TEM, SHV-ESBL genes. SHV $\beta$-lactamases enzymes are mainly found in G-ve bacteria (HUANG et al. 2004).

The analysis of TLC revealed the presence of brown spot on thin layer chromatography in the same local with standard (EFA omega 3 ) and both of them gave $\mathrm{Rf}=0.37$ these results in accordance with PANDYA et al. (2013) who explained that EFA - omega 3 by use hexan solvent gave Rf value 0.34 and with AHMAD et al. (2017) who founded that Rf value $=0.36$.

The fourteen isolates that revealed $\beta$-lactam resistance antibiotics were choosen to examine the impact of EFASC extracts. The result of antibacterial activity illustrated that highly effect of different concentrations $(62.5,125,250$ and $500 \mathrm{mg} / \mathrm{ml})$ of EFASC which illustrated the susceptibility of resistance isolate to EFASC.

The inhibition zone of EFASC of flaxseed was $29 \pm 0.93 \mathrm{~mm}$ against $C$. freundii and $\mathbf{3 1} \pm \mathbf{0 . 9 3} \mathrm{mm}$ against $C$. koseri in concentration $500 \mathrm{mg} / \mathrm{ml}$, Table 4 . In general 12 of $14(85.7 \%)$ resistant bacteria were inhibit their growth by using different concentration of EFASC. Results of AHMAD et al. (2017) also show that EFASC of seed oil possess good antibacterial activity against nosocomial infection bacteria. In the same line (BORHADE 2014) indicated the strong effect of EFASC against $E$. coli and $S$. aureus at varied level and compatible with study by(SEIDEL \& TAYLOR (2004) they found that the antibacterial action of fatty acids is usually attributed as being a property of the long-chain unsaturated fatty acids, including oleic acid, linoleic acid, and linolenic acid. MOGENSEN (2009) mention that polyunsaturated essential fatty acid play role in inhibition the growth of bacteria that containing a penicillinase plasmid. In this regard (IBARGUREN et al.2014) explain that fatty acid modulate the fluid 
permeability of cell membranes which can greatly affect membrane property.

Therefore EFASC consider useful approach in treatment wide range of antibiotic resistant bacteria because they are safe and dependable with less harmful than antibiotic which more cost, have side effect and most bacteria became resist against it.

\section{REFERENCES}

Ahmad A. A., Darweesh M. A. \& Ahmad A. M. 2017. The Antibacterial of Essential Fatty Acid Semicarbazide Extracted from Flaxseed Oil Against Some Nosocomial Infection Bacteria in Iraq. IJCPR; 8(1) January- February: 31-39.

Al-Hasnawi A. A. 2014. Comparison of biochemical tests, Api system, Vitek 2 system and PCR of the enteropathogenic bacteria isolated from children with persistent diarrhea. And the occurrence of virulence factors and antibiotic resistance in the isolates.Master Thesis. Faculty of Science, University of Kufa.

Al-Hissnawy D., Al-Thahab A. \& AL-Jubori S. 2012. Evaluation of Citrobacter freundii isolated in Najaf governorate as an enterotoxin producer. Medical J. of Babylon. 9(1): 1-5.

Al-MuhannaK F. H. N. 2010. Spread of Some Extended Spectrum Beta-Lactamases in Clinical Isolates of Gram Negative Bacilli in Najaf. M.Sc. Thesis. College of Medicine, University of Kufa.

Al-Muslemawi TH. A. 2007. Study of some biochemical, biological and pathological properties of lipopolysaccharide extracted from Citrobacter freundii. Ph.D. Thesis. Baghdad univ.

Batchoun R. G., Swedan S. F. \& Shurman A. M. 2009. Extended spectrum $\beta$-lactamases among Gramnegative bacterial isolates from clinical specimens in three major hospitals in Northern Jordan. J. Micro. Res. Article, ID 513874.

BoRHADE S. 2014. Synthesis, Characterisation and Antimicrobial Activity of Essential Fatty Acid of Semicarbazide. Int. J. of Chem. Scie. and Applic. 5(2): 46-55.

Bush K., JACOBY G. \& Medeiros A. 1995. A functional classification scheme for $\beta$-lactamases and its correlation with molecular structure. Anti. Agents Chemo. 39: 1211-1233.

CLSI 2014. Performance Standards for Antimicrobial Susceptibility Testing: Twenty - Fourth Informational Supplement M02- A11, M 0-A11, and M11-A8. Wayne, PA, USA.

Colom K., Perez J., Alonso R., Fernandez-Aranguiz A., Eva Larino E. \& Cisterna R. 2003. Simple and reliable multiplex PCR assay for detection of blaTEM, blaSHV and blaOXA-1 genes in Enterobacteriaceae. FEMS Microbiology Letters, 223: 147-151.

DANCER S. J. 2001. The problem of Cephalosporin. J. of Antimic. Chemo. 48: 463-478.

Desbois A. P. \& LAWLOR K. C. 2013. Antibacterial Activity of Long-Chain Polyunsaturated Fatty Acids against Propionibacterium acnes and Staphylococcus aureus. Mar. Drugs 11: 4544-4557.

Egharevba H. O., Kunle O. F., IliYa I., ORJi P. N., Abdullahi M. S., OKwute S. K. \& OKogun J. I. 2010. Phytochemical analysis and antimicrobial activity of Punica granatum L. (fruit and leaves). New York Scie. J. 3(12): 91-98.

ERLANDSSON M. 2007. Surveillance of antibiotic consumption and antibiotic resistance in Swedish intensive care units. Linkoping University Medical Dissertations No. 1019 Sweden.

FuAD M. M. H., Ferdowsy H., Hossain M. N., Foysal M. J. \& RAHMAn M. M. 2012. In Vitro Antibacterial Activity of Common Antibiotics and Herb Extracts to Clinical Isolates of Escherichia coli Collected from UTI Patient. Int. J. of Rese in Pharmacel and Biomedi Sciences. 3(2): 987-992.

Harborne J. B. 1984. Phytochemical Methods.; A Guide to Modern Techniques of Plant Analysis, 2nd ed. Chapman and Hall, London

HaRvey R. A. \& Champe D. C. 2012. Lippincott's Illustrated Reviews: Pharmacology $5^{\text {th }}$ ed., Lippincott Williams and Wilkins, USA. 382-385.

Hassan M. M., GABer A., ATtiA O. A. \& Ayman R. B. 2014. Molecular characterization of antibiotic resistance genes in pathogenic bacteria isolated from Patients in Taif Hospitals, KSA. AJPCT. 2(8): 939-951.

Hassan M., Alkharsah K. R., Alzahrani A. J., Obeid O. E., Khamis A. H. \& Diab A. 2013. Detection of extended spectrum beta-lactamases-producing isolates and effect of AmpC overlapping. Infect. Dev., 7(8): 618-629. 
Huang Z. M., Mao P. H., Chen, Y.; Wu, L. AND WU, J. (2004). Study on molecular epidemiology of SHV type beta-lactamase encoding genes of multiple-drug - resistant Acinetobacter baumannii. Zhonghua Liu Xing Bing Xue Za Zhi.,25: 425-427.

IbARguren M., Lopez D. \& EsCriBA P. 2014. The effect of natural and synthetic fatty acids on membrane structure, microdomain organization, cellular functions and human health. Biochi. et Bioph. Acta. 1838: 1518-1528.

JANDA J. M., ABвott S. L., ChEUnG W. K. \& HANSON D. F. 1994. Biochemical identification of citrobacteria in the clinical laboratory. J of Clini Microbi. 32(8): 1850-1854.

MACFADDIN J. E. 2000. Individual Biochemical Tests For Identification of Medical Bacteria. 3th ed. Lippincott Williams Wilkins, London: 57-424.

Metri B. C., Jyothi, V. X. \& Peerapur B. V. 2013. Antibiotic resistance in Citrobacter spp. isolated from urinary tract infection. Urol Ann. Oct-Dec; 5(4): 312-315.

Mogensen T. H. 2009. Pathogen recognition and inflammatory Signaling in innate immune. Defenses. Clin. Micro. Rev. 22(2): 240-273.

Nada T., Baba H., Kawamura K., Ohkura T., Torit K. \& Ohta M. A. 2004. Small outbreak of third generation cephem-resistant Citrobacter freundii infection on a surgical ward. JPN. Journal of Infectious Diseases. 57: 181-182.

Pandya P., Harisha C. R., Shandla V. J. \& Chandola H. M. 2013. Pharmoacogostical and Photochemical evaluation Atasi (Linum ustatissimmum L.). Indian Journal of Tradition Knowledge. 12(4): 688-692.

Perilli M., Mugnaioli C., Luzzaro F., Fiore M., Stefani S., Rossolini G. \& Amicosante G. 2005. Novel TEM-type extended-spectrum beta-lactamase, TEM-134, in a Citrobacter koseri clinical isolate. Antimicrob. Agents Chemother. 49: 1564-1566.

Salih M. K., Alrabadi N. I., Thaliu K. M. \& Hussien A. S. 2016. Isolation of Pathogenic Gram-Negative Bacteria from Urinary Tract Infected Patients. Open Journal of Medical Microbiology, 6: 59-65.

Sami H., Sultan A., Rizvi M., Khan F., Ahmad Sh., Shukla I. \& Khan H. 2017. Citrobacter as a uropathogen, its prevalence and antibiotics susceptibility pattern. 4(1): 23-26.

SEIDEL V. \& TAYLOR P. W. 2004. In vitro activity of extracts and constituents of Pelagonium against rapidly growing mycobacteria. Int. J. Antimicrob. Agents, 23: 613-619.

SHAHID M. 2010. Citrobacter spp. Simultaneously harboring bla- CTX-M, blaTEM, blaSHV, bla-ampC, and insertion sequences IS26 and orf513: an evolutionary phenomenon of recent concern for antibiotic resistance. J of Clin. Microbi. 48(5): 1833-1838.

Shin C.-C., Chen C., Chang S.-C., LuH K.-T. \& HsieH W.-C. 1996. Bacteremia due to Citrobacter species: significance of primary intraabdominal infection. Clinical Infectious Diseases. 23(3): 543-549.

SHIN S. Y., BAJPAI H. R. \& KANG S. C. 2007. Antibacterial activity of ecosapantaenoic acid (EPA) against foodborne and food spoilage microorganism. LWT - Food Sci. Tech., 40: 1515-1519.

Singhal M. \& PAUL A. 2011. Antibacterial evaluation of synthesized methyl semicarbazone derivatives. IJPSR. 2(10): 2602-2604.

Stewart Z. E., Shaker M. \& BAXTER J. D. 2017. Inflammation and Infection Urinary Tract Infection Caused by Citrobacter koseri in a Patient With Spina Bifida, an Ileal Conduit and Renal Caluli Progressing to Perinephric Abscess and Empyema. Urology Case Reports 11: 22-24.

SVÄRD L. 2007. Evaluation of phenotypic and genotypic extended spectrum beta-lactamase detection method. M.Sc. Thesis. School of Biological Sciences, Dublin Institute of Technology, Uppsala University, Germany.

TuwaiJ N. S. 2016. Molecular Study of Quinolone Resistance in Klebsiella pneumoniae and Citrobacter freundii Isolates. Al-Kufa University J. for Biology 8(3): 300-312.

Wang H., Wang J., Qiu C., Ye Y., Guo X., Chen G., Li T., Wang, Y., Fu X. \& LiU R. 2017: Comparison of phytochemical profiles and health benefits in fiber and oil flaxseeds (Linum usitatissimum L.). Food Chem. Jan 1; 214: 227-233.

WARREN J., FARMER J., DeWhirst F., BirkHED K. \& ZEMbOWER T. 2000. Out break of nosocomial infection due to extended - spectrum beta- lactamase producing strain of enteric group 137, a new member of the family Enterobacteriaceae closely related to citrobacter farmer and C. amalonatica. J. Clin. Microbio. 38(11): 3946-52. 